\title{
The Value of the Revolving Door Political Appointees and the Stock Market
}

\section{Working Paper}

\section{Author(s):}

Lüchinger, Simon; Moser, Christoph

Publication date:

2012-08

Permanent link:

https://doi.org/10.3929/ethz-a-007362333

\section{Rights / license:}

In Copyright - Non-Commercial Use Permitted

Originally published in:

KOF Working Papers 310 


\section{KOF Working Papers}

The Value of the Revolving Door:

Political Appointees and the Stock Market

Simon Luechinger and Christoph Moser

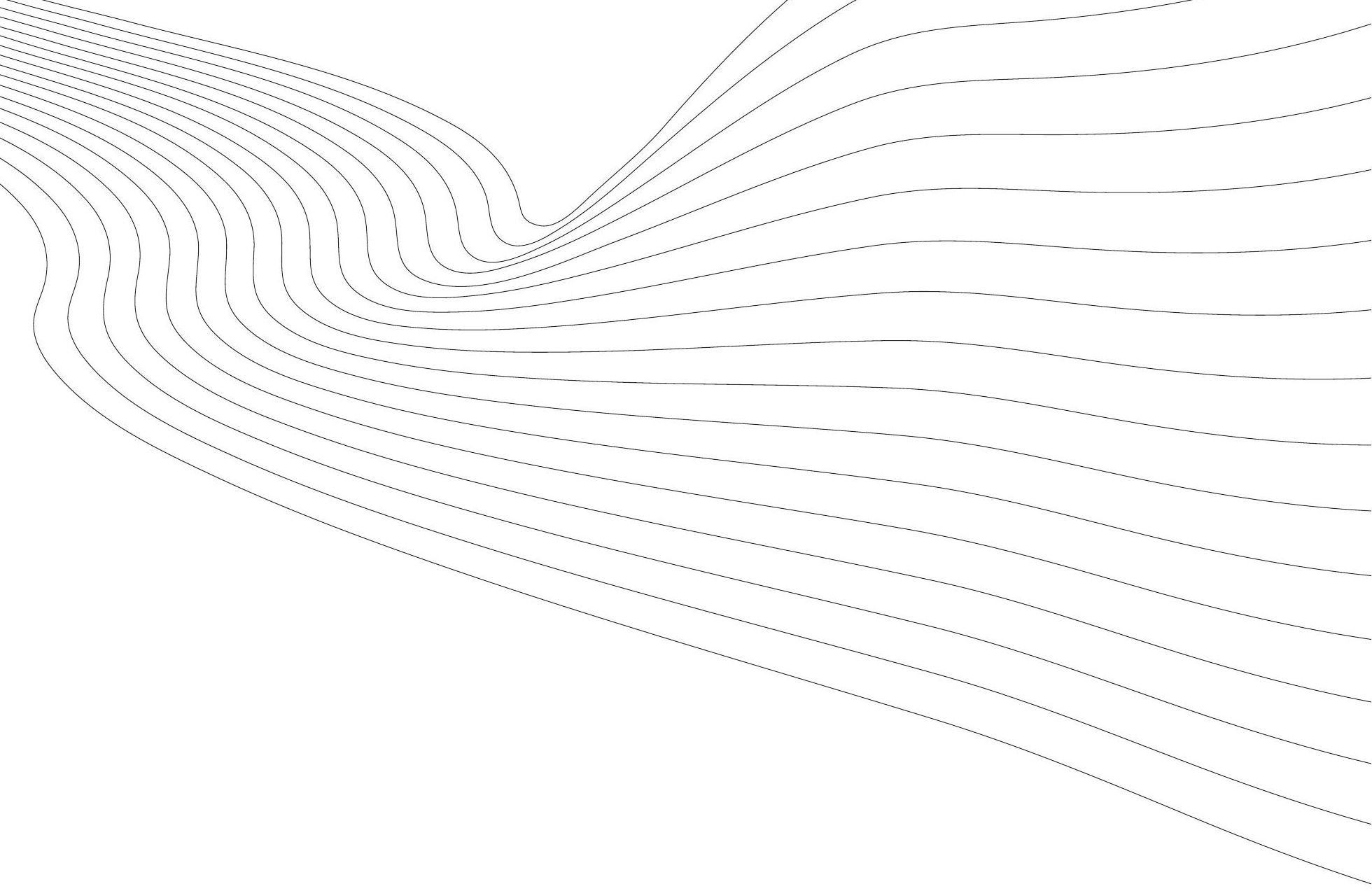




\section{KOF}

ETH Zurich

KOF Swiss Economic Institute WEH D 4

Weinbergstrasse 35

8092 Zurich

Switzerland

Phone +41446324239

Fax +41446321218

www.kof.ethz.ch

kof@kof.ethz.ch 


\title{
The Value of the Revolving Door: Political Appointees and the Stock Market
}

\author{
Simon Luechinger ${ }^{\text {a), b) }}$ and Christoph Moser ${ }^{\text {b), c) * }}$ \\ a) University of Lucerne, \\ ${ }^{b)}$ ETH Zurich, KOF Swiss Economic Institute \\ c) CESifo
}

August 20, 2012

\begin{abstract}
We analyze stock market reactions to announcements of political appointments from the private sector and corporate appointments of former government officials. Using unique data on corporate affiliations and announcements of all Senate-confirmed U.S. Defense Department appointees of six administrations, we find positive abnormal returns for political appointments. These estimates are not driven by important observations, volatile stocks or industry-wide developments. Placebo events yield no effects. Effects are larger for top government positions and less anticipated announcements. We also find positive abnormal returns for corporate appointments. Our results suggest that conflicts of interest matter also in a country with strong institutions.
\end{abstract}

JEL: G14, D73, G30, H57.

Keywords: Political appointees, revolving door, conflict of interest, event study, stock market

\footnotetext{
* Address for correspondence: ETH Zurich, KOF Swiss Economic Institute, Weinbergstrasse 35, 8092 Zurich, Switzerland. E-mail: Christoph Moser (moser@kof.ethz.ch); Simon Luechinger (simon.luechinger@unilu.ch). We thank Philipp Rückheim, Heysook Shin and Omar Abdel Rahman for excellent research assistance. For comments and suggestions we thank Steffi Bansbach, Philipp Denter, Tim Friehe, James Kolari, Francis Kramarz, James Kwak, Sara Lovell, Nolan McCarty, Bernhard Obenhuber, Tobias Seidl and Joachim Voth as well as seminar participants at the KOF Swiss Economic Institute, the $5^{\text {th }}$ BBQ Conference in Schiermonnikoog, University of Konstanz and Vienna University of Economics and Business and participants at the annual meeting of the Swiss Society of Economics and Statistics.
} 


\section{Introduction}

When President Obama took office in January 2009, he faced a challenge common to incoming Presidents in the United States: Filling top-positions in the federal administration with political appointees. Among other sources, he tapped the reservoir of private sector experts, like all Presidents before him. For example, William J. Lynn III, a Pentagon official under Clinton and later Raytheon executive, was his nominee for Deputy Secretary of Defense. But the revolving door spins in both directions: Legions of leaving Bush appointees joined the industry.

The academic literature on political appointments stresses the trade-off between a decrease in competence and an increase in political control (e.g., Lewis, 2008; Huber and McCarty, 2004). Political appointees lack site-specific knowledge and institutional memory, but shared preferences, aligned incentives and lower informational asymmetries increase the control of elected officials over the bureaucracy. In contrast, the public debate often revolves around the value of industry expertise for regulation or procurement and concerns about potential conflicts of interest. Commenting on Lynn's nomination, a defense analyst said, "On the one hand, if you don't have defense-industry experience, then you're lacking critical insight. On the other hand, if you do, it's inevitable that in some way it's going to impact on your

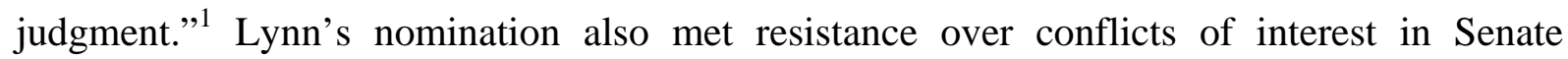
hearings: “[T]he revolving door is an important issue for us to talk about, between the Pentagon and the defense community. You went directly from the Pentagon to a defense contractor. You are coming back directly from a defense contractor [...] into the Department of Defense. [...] This is troubling to a lot of people [...] and it's an incestuous business what's going on in terms of the defense contractors and the Pentagon [...].”2

Concerns over potential conflicts of interest are not unfounded. Political appointees have both opportunities and motives to act in favor of their former employers. Preferential treatments can come in different disguises: Directly in procurement, regulation and oversight, and supervision of mergers and acquisitions; indirectly in strategic planning and preferential access to decision makers and information. At the same time, political appointees also have incentives for preferential treatment towards their former employers either because they expect to rejoin the companies or because they want to return favors. Similarly, former political appointees bring valuable connections and information about processes, upcoming

\footnotetext{
${ }^{1}$ Loren Thompson cited in Defense Daily, “Lynn confirmation vote expected today,” February 11, 2009.

${ }^{2}$ Sen. Claire McCaskill cited in Federal News Service, "Hearing of the Senate Armed Services Committee confirmation hearing on expected nominations by President-elect Barack Obama,” January 15, 2009.
} 
decisions and competitors to firms hiring them upon leaving government service. However, the generally favorable institutional environment of the United States with checks and balances and a free press as well as specific institutional safeguards embodied in ethic rules counter such concerns. Whether conflicts of interest exist and whether firms can benefit from them are ultimately empirical questions.

Do firms profit from the political appointment of one of its members? Do firms profit from hiring a former political appointee? These two questions lie at the heart of this paper. We address these questions with an event-study. We estimate the effect of announcements of appointments and hirings on firm value. Given that stock prices reflect expected future profits and any news affecting these expectations is immediately priced in by financial markets, stock price reactions to the announcements measure the value of political connections associated with the revolving door. Thus, positive stock market reactions are consistent with the view that conflicts of interest indeed matter.

Event studies have several advantages over alternative approaches. Compared to effects on realized firm performance or the volume of procurement contracts, effects on stock prices are immediate. Thus, it is easier to relate cause and effect and abstract from confounding factors. Further, unlike effects on the volume of procurement contracts, stock price reactions are a comprehensive measure for the value of political connections. Compared to respondents in surveys and expert interviews, financial market participants have a strong financial interest for well-informed and unbiased assessments.

In our empirical analysis, we concentrate on political appointees in the United States Department of Defense. This department is by far the largest department in terms of budget, amounting to over USD 700 billions including supplementals in recent years, and in terms of procurement volume (Gansler, 2011). Furthermore, it has around 700,000 civilian employees and the largest number of executive political appointees, i.e., excluding attorneys, marshals and ambassadors (Lewis, 2008). Thus, focusing on the Department of Defense assures a large and homogenous sample. We cover appointees nominated by or serving under Presidents Bush Sr. to Obama. In other words, our analysis encompasses six administrations and over 20 years. We consider the universe of Senate confirmed positions at the Department of Defense, totalling 527 person-position combinations or 383 individuals. For these observations we reconstruct the employment and affiliation history within two years of government service and gather the exact date of political and corporate appointments through a full-text search using LexisNexis and SEC-filings. We consider an appointee to be connected to a firm, if she 
has served as a member of board of directors or advisory board, an executive officer or an employee of that firm. We then link the information on political and corporate announcements to daily stock market data of these connected firms. This yields a sample of 85 observations (72 firms and 58 persons) related to political appointments and 85 observations (75 firms and 59 persons) for corporate hirings of former government officials. We use these data and a standard market model approach to estimate abnormal returns for each announcement.

To anticipate our main findings: For political appointments (“ex ante”), we find positive average abnormal returns of $0.82 \%$ and $0.84 \%$ for the one- and two-day event windows, respectively. Abnormal returns are larger for (former) board members, top pay-grades in the Department of Defense, appointees nominated by a Democratic administration (for the oneday window) and for those events, where the announcement was at least partly unanticipated. But the revolving door works in both ways. For corporate appointments (“ex post”), the announcement results in average positive abnormal returns of $0.79 \%$ and $1.05 \%$ for one- and two-day event windows, although these results are statistically less strong. We find that stock market reactions tend to be higher for nominations to the board of directors and for corporate appointments of former political appointees of a Democratic President. The baseline results are robust to the exclusion of extreme abnormal returns, scaling of abnormal returns and the adjustment of returns by industry returns. Placebo events yield no effects.

Our paper is related to five different strands of the literature: The literature on the value of political connections established by (i) political appointments and (ii) corporate appointments of former government officials in the United States, (iii) of political connections more generally, (iv) the literature on lobbying, and (v) the literature on the reaction of defense stocks to political decisions.

Closest in spirit to our paper is Fisman, Fisman, Galef and Khurana (2006), who investigate the value of connections to Vice President Richard Cheney. ${ }^{3}$ Firms are defined as connected if either Cheney was on the board of directors or if one of their board members served on Halliburton's board during Cheney’s watch as chairman and CEO. Fisman et al. (2006) do not find any significant stock market reactions to important news about Cheney and his health. This suggests that the checks and balances of U.S. institutions are strong enough to keep conflicts of interest in check. Another related paper is Acemoglu, Johnson, Kermani, Kwak and Mitton (2010), who document strong and positive abnormal stock returns for firms being

\footnotetext{
${ }^{3}$ The Vice President of the United States is "hand-picked" by the presidential candidate, formally selected by the nominating conventions, and finally elected by the Electoral College. Hence, strictly speaking, the Vice President is not a political appointee.
} 
seen as close to the new U.S. Treasury Secretary, Timothy Geithner, upon his appointment amidst the Subprime Crisis in November 2008. Acemoglu et al. (2010) measure connections to Geithner in three ways - two related to his former position as head of the New York Federal Reserve Bank and one based on personal connections as captured by muckety.com and results are fairly similar across these different variables. Thus, these two papers provide mixed evidence on the value of political connections in the United States. Our paper differs from these papers in several respects. Acemoglu et al. (2010) are not concerned with the revolving door or conflicts of interest stemming from political appointments of individuals from the private sector. Similarly, only a small subset of the political connections studied by Fisman et al. (2006) is related to the revolving door phenomenon. Both papers provide valuable insights into the value of political connections for one politician and appointee, respectively. In contrast, our paper is based on a large number of appointees over more than two decades. At the same time, appointees are from one department, assuring a homogenous sample. Importantly, we also include below cabinet level positions. As the tanker-leasing scandal has demonstrated, political appointees at lower levels have opportunities for preferential treatment of specific firms. Darleen A. Druyun, acting Assistant Secretary of the Air Force (Acquisition), gave Boeing Company an inflated price on the contract and shared confidential information about a competitor in return for a generous job deal at Boeing. ${ }^{4}$ Moreover, sub-cabinet level appointees are more likely to fly under the radar of the media.

Although we look at both sides of the revolving door, our main focus is on political appointments. In our view, conflicts of interest are more worrisome, when political appointees are in office and can exert direct influence within the administration in favor of their former employers. Nevertheless, we also look at corporate appointments of former government officials. In this context, the study of Goldman, Rocholl and So (2009) is closely related to ours. ${ }^{5}$ Goldman et al. (2009) analyze announcements of corporate board appointments of individuals who at any time of their past career held a high political position and who served on the boards of S\&P 500 from 1996 to 2000. Differences to our study exist with regard to corporate affiliations. We consider executive appointments in addition to board appointments and include all listed firms. Our results generally confirm the findings of Goldman et al. (2009). They find positive abnormal returns for corporate appointments. To highlight two

\footnotetext{
${ }^{4}$ Associated Press, "Boeing fires two executives for unethical conduct in tanker-leasing case," November 24, 2003 and Associated Press, "Former Boeing executive gets four months in prison,” February 18, 2005.

${ }^{5}$ We focus in our discussion of Goldman et al. (2009) on the section closest to our empirical strategy. Goldman et al. (2009) also exploit the close presidential election in 2000 and the partisanship of the board members. Other papers focusing on this election include Knight (2006) and Snowberg, Wolfers, and Zitzewitz (2007). While this empirical strategy is convincing in their context, it would not be helpful in our case, since most political appointees are not even perceived as candidates at the time of presidential elections.
} 
further interesting results: Corporate announcement-effects are more pronounced for companies connected to the Democratic party and there are no positive abnormal returns for comparable board nominations of not politically connected candidates to the same company.

An important and growing literature assesses the value of political connections more generally, mainly in countries with weak institutions. In a seminal paper, Fisman (2001) demonstrates that political connections to the Suharto family were very valuable during Indonesian President Suharto’s reign. For identification, he exploits negative news about the health of the elderly President and its effect on Indonesian stock returns. Similarly, Johnson and Mitton (2003) establish that connections to Malaysia’s Prime Minister Mahathir paid out in the aftermath of the Asian financial crisis. Ferguson and Voth (2008) show that firms with close links to the National Socialist German Workers' Party enjoyed strong, positive abnormal returns during Hitler's accession to power in 1932-1933. For Thailand, Bunkanwanicha and Wiwattanakantang (2009) find not only that higher wealth and dependence on regulated industries make business leaders more likely to run for public office, but that their firms gain in market value during their tenure. Finally, in another seminal paper, Faccio (2006) documents that corporate political connections are widespread in a large crosssection of 47 countries. These connections can add to firm value, even though this holds true only for countries with weak institutions, when large shareholders or top executives get elected into a high political position. ${ }^{6}$

There is empirical evidence for different channels through which political connections are valuable for firms in developing countries. Politically connected firms enjoy preferential access to finance, government bail-out or profit from regularity changes. ${ }^{7}$ For the United States, Goldman, Rocholl, and So (2010) are the first to provide evidence for a specific channel of political connections. Their study shows that firms with former politicians on the board of directors enjoy higher growth in procurement contracts after a change in the political landscape. Interestingly, these networks through former politicians are apparently more important for procurement than firms' campaign contributions. ${ }^{8,9}$

\footnotetext{
${ }^{6}$ Analyzing the effect of geographical ties, i.e., firms headquartered in birth or home towns of politicians, Faccio and Parsley (2009) confirm that political connections matter more in countries with weaker institutions. However, Roberts (1990) found geographical ties to matter even in the United States.

${ }^{7}$ See Khwaja and Mian (2005), Faccio, Masulis and McConnell (2006), Leuz and Oberholzer-Gee (2006), Claessens, Feijen, and Laeven (2008) and Bunkanwanicha and Wiwattanakantang (2009) for this evidence.

${ }^{8}$ For the literature on political connections established through firms' campaign contributions to parties or specific politicians in the United States, see among others Roberts (1990), Jayachandran (2006), Cooper, Gulen and Ovtchinnikov (2010) and Huber and Kirchler (2012).

${ }^{9}$ Bertrand, Kramarz, Schoar and Thesmar (2007) provide evidence that political connections can also entail higher labor costs for connected firms in France.
} 
Lobbying is often seen as another way through which firms seek to influence government decisions. ${ }^{10}$ Two innovative recent studies suggest that corporate lobbying in the United States indeed adds to firm value. Borisov, Goldman and Gupta (2011) exploit a top lobbyist’s corruption scandal and consequent heightened public scrutiny of lobbying and show stronger negative market reactions to this news for firms with higher lobbying expenditures. Blanes $\mathrm{i}$ Vidal, Draca and Fons-Rosen (2012) analyze the lobbying effect of former government officials on lobbying firm's revenue and find that personal connections to U.S. Senators are of substantial value to these firms. In contrast to these studies, the focus of our paper is on personal ties through corporate affiliations and not on lobbying. Furthermore, lobbying firms cannot enter our event study, since they are not listed on the U.S. stock market.

Finally, our paper is related to the literature on the reaction of defense stocks to Department of Defense decisions. ${ }^{11}$ Rogerson (1989) estimates the value of contract awards of major weapon systems. There is often competition in the development phase, but later one company typically becomes the sole supplier and earns economic profits (see also Lichtenberg, 1989; Gansler, 2011). Analyzing stock market reactions to the announcements of twelve aerospace contract award decisions, Rogerson (1989) indeed finds evidence for expected profits. In another event study, Karpoff, Lee and Vendrzyk (1999) demonstrate that firms responsible for defense procurement fraud are penalized by financial markets, but this penalty is smaller for established contractors. Finally, Bechtel and Schneider (2010) document that European defense stocks rise due to EU summit decisions that strengthen Europe's military capacity. Although these papers are loosely related to our paper, our study is not primarily or exclusively about the defense sector, but about the value of political connections for corporations more generally. The Department of Defense is also important for many firms beyond the defense sector. ${ }^{12}$

The remainder of the paper is organized as follows. Section 2 discusses why and how (former) political appointees could preferentially treat their (former) employers. Section 3 provides a description of the data and outline of the empirical strategy. Section 4 presents the empirical results and Section 5 offers concluding remarks.

\footnotetext{
${ }^{10}$ For an excellent overview of in-house lobbying and lobbying for other firms in the United States, see Bertrand, Bombardini and Trebbi (2011).

${ }^{11}$ For excellent surveys on the economics of defense procurement and the defense industry, see Rogerson (1994), Kovacic and Smallwood (1994) and Gansler (2011). A major question in this literature is how innovation can be secured and costs controlled in a heavily regulated sector, where the government is often the sole purchaser of goods.

12 This fact is vividly exemplified by a Senate rule requiring political appointees to divest from bonds and stocks in over 48,000 companies with contracts with the Department of Defense (see Washington Post, "Senate panel ban seen as double standard”, December 19, 2010).
} 


\section{Background}

The revolving door between industry and government entails potential conflicts of interest. Political appointees can both directly and indirectly act in favor of their former employers and they have various motives to do so. In a similar vein, former government officials have different means to bring value to firms hiring them. But there are numerous institutional safeguards at all levels preventing conflicts of interest. These arguments will be outlined in more detail in the remainder of this section.

The potential of direct preferential treatment is probably most obvious in procurement. Political appointees are involved in decisions affecting their former employers at all stages of the procurement process. When Gerald A. Cann, General Dynamics Corp.'s former chief of undersea warfare, became Assistant Secretary of the Navy (Research, Development, and Acquisition), he had to select among three standoff anti-submarine weapons, one of which he developed at his former employer. "It is a little wrong to be involved with a weapon system [in industry] and then be put in charge of deciding [at the Department of Defense] what system will replace the one that's performing the mission now," said Sen. Al Gore. ${ }^{13}$ When James G. Roche, a former Northrop Grumman Corp. executive, served as Secretary of the Air Force, he was the source selection authority in the F-35 competition and his former employer a main partner of one of the bidders. This team ultimately won and was expected "[...] to dominate warplane construction worldwide for the first half of this century.”14

Direct preferential treatment is also possible in case of regulation and oversight and supervision of mergers and acquisitions. As Assistant Secretary of the Air Force (Installations and Environment) Terry A. Yonkers was in charge of drafting environmental regulations of the Air Force, affecting his former employer Arcadis NV. ${ }^{15}$ John M. Deutch, Under Secretary of Defense (Acquisition, Technology, and Logistics), followed an initiative of Martin Marietta's head and approved a new rule allowing the Department of Defense to partly cover merger costs. Later, as Deputy Secretary of Defense, he gave the nod to the merger between Lockheed Corp. and Martin Marietta Corp. ${ }^{16}$ This merger eventually cost the Department of

\footnotetext{
${ }^{13}$ Cited in Aerospace Daily, “Navy official denies conflict of interest with Tomahawk variant,” June 10, 1991.

${ }^{14}$ Washington Post, "Decision on Joint Strike Fighter; Lockheed Martin and Boeing competing for huge Pentagon jet contract," October 21, 2001.

${ }^{15}$ Washington Times, "Conflicts aplenty for Obama nominees; yet another pick undercuts new influence policies,” November 12, 2009.

${ }^{16}$ Associated Press, “Pentagon endorses merger of Lockheed and Martin Marietta,” December 29, 1994.
} 
Defense more than USD 1 billion. ${ }^{17}$ Did we mention that he was formerly a member of the advisory board of Martin Marietta Corp.?

Political appointees can also influence the fate of their former employers in less direct ways. In particular, strategic planning can have important long-lasting implications on the Pentagon budget and prospective contractors. Thomas E. White pushed for the privatization of army base utilities, both as an Enron Corp. executive and later as the Secretary of the Army. ${ }^{18}$ At the time of the nomination of the Northrop Grumman executive Donald C. Winter as Secretary of the Navy, a debate over the future of Navy shipbuilding was ongoing with Northrop Grumman Corp. being one of the key players. ${ }^{19}$

Firms also potentially profit from better access to decision makers and information, if one of their members joins the Pentagon. Sen. Claire McCaskill worried that "[...] there is maybe too much shortcutting of picking up the phone and dialing into the Pentagon from a defense contract agency because of former friends that are there and vice versa?"20 Indeed, Thomas E. White acknowledged such contacts and attempted contacts with former Enron colleagues on various occasions and Donald C. Winter met Northrop Grumman's CEO for a private luncheon (as he did with some other defense executives). ${ }^{21}$

Political appointees have not only opportunities but also incentives to favor their former employers. They may expect to return to the company or at least want to keep this option alive. One prominent returnee is the Deputy Secretary of Defense and Secretary of Defense William J. Perry, who re-joined the board of directors of United Technologies Corp. after his stint at the Department of Defense. Further, political appointees may simply wish to return previous favors, such as generous help in the nomination process or lavish retirement bonuses. Enron supported Thomas E. White's nomination with a letter of recommendation by the

\footnotetext{
${ }^{17}$ Washingtonian, "Mission impossible; John Deutch is quick, smart, and tough -- and a poster boy for the military-industrial-academic complex; with the central intelligence agency in shambles, does he have what it takes to save it?” November 1995.

${ }^{18}$ Associated Press, “Military utilities may go private,” June 19, 2001. New York Times, “Enron’s collapse: The Secretary; army chief being challenged on ties to company," January 25, 2002. Washington Post, "Pentagon official from Enron in hot seat; questions raised about Army Secretary White and possible conflicts of interest," January 27, 2002.

${ }^{19}$ Defense Daily, “Northrop Grumman executive’s bid for SECNAV raises conflict of interest fears," September 23, 2005.

${ }^{20}$ Cited in Federal News Service, "Hearing of the Senate Armed Services Committee confirmation hearing on expected nominations by President-elect Barack Obama,” January 15, 2009.

${ }^{21}$ Washington Post, “Army Secretary defends support from Enron,” April 5, 2002. Defense Daily, "SECNAV Winter wins ethics waivers for work on Northrop Grumman issues,” March 24, 2006.
} 
Chairman and by rides in the company's jet and Donald C. Winter received several million dollars on his way out of the door of Northrop Grumman. ${ }^{22}$

There are various reasons why firms can benefit from hiring former government employees (see also Agrawal and Knoeber, 2001, Goldman et al., 2009, 2010). Former political appointees are valuable because of their connections, access and clout. ${ }^{23}$ According to Washington insiders, schmoozing government officials at all stages of the procurement process is essential for landing contracts. ${ }^{24}$ Probably, nobody is better qualified for this job than former political appointees. Furthermore, former political appointees have precious knowledge and information. First, they have considerable institutional insights and can instruct companies in the way the Pentagon works. ${ }^{25}$ Second, they have inside information about upcoming decisions. According to retired Admiral Robert Inman, former Secretary of Defense nominee and long-time SAIC board member, "[t]hese people bring with them years of experience and can help the company identify what's ahead so they can better anticipate and prepare for the future.”26 Third, during their term, political appointees gain special insights into competitors of their future employers. ${ }^{27}$

A favorable institutional environment - like a vigilant free press, independent watch dogs and congressional committees - and specific provisions are likely to prevent fraud and abuse and keep potential conflicts of interest in check in the United States. Numerous ethic regulations aim at preventing improper behavior. Prime among these are recusal requirements for political appointees in decisions affecting their former employers, demands to sever financial interests with companies doing business with the Pentagon by divesting from stock positions and by insuring pension claims, and prohibitions to lobby former colleagues during a cool-off period upon leaving the administration. Yet, despite numerous rules on the books, it is less clear to what extent they are actually enforced. While Senators usually take a tough stand during the confirmation hearings, political appointees are often successful in receiving waivers later on. For instance, in the confirmation process of the former corporate executives and service secretary nominees, Thomas E. White and Donald C. Winter, the members of the Senate

\footnotetext{
${ }^{22}$ Washington Post, “Army Secretary defends support from Enron,” April 5, 2002. Defense Daily, "SECNAV got several million dollars from Northrop Grumman before taking job,” April 14, 2006.

${ }^{23}$ This view was expressed for instance by the Director of of the Center for Public Integrity in Associated Press, "Half of top Clinton aides now lobbyists trying to use Washington influence," March 30, 2003.

${ }^{24}$ Government Executive, "Schmooze or lose: Contractors rely on personal connections and insider information to win contracts,” December 1, 2005.

${ }^{25}$ Washington Post, "Recruiting Uncle Sam; the military uses a revolving door to defense jobs,” February 19, 2004.

${ }^{26}$ San Diego Union-Tribune, “SAIC uses big bucks, makes powerful friends,” November 12, 1995.

${ }^{27}$ Washington Post, “A revolving door? So what?” July 2, 2003.
} 
Armed Services Committee took ethic issues very seriously. ${ }^{28}$ However, Donald C. Winter won waivers on the rule requiring nominees to buy pension insurance and to participate in decisions regarding his former employer. ${ }^{29}$ Thomas E. White failed to divest from his Enron financial positions in time and to notify the Congress. ${ }^{30}$ On the very same day that President Obama tightened recusal requirements, William J. Lynn, III, received a waiver from this rule. President spokesman defended this move: "Even the toughest rules require reasonable exceptions.” ${ }^{31}$ Enforcement seems to be especially sloppy when it comes down to postemployment restrictions (Mackenzie, 1987; Rasor and Bauman, 2007).

Given these considerations, it is an empirical question, whether firms indeed profit from the revolving door. Therefore, we now turn to our empirical analysis.

\section{Data and Empirical Strategy}

We gather data for all political appointees in positions of the U.S. Department of Defense requiring Senate confirmation. For political appointments, we consider announcements for the six administrations from Bush Sr. to Obama. Similarly, for corporate appointments, we include all announcements regarding appointees, who served in these administrations.

We identify the persons holding these positions on the basis of Department of Defense (2004), the Plum Book (Government Printing Office, various years), the THOMAS database of the Library of Congress and other documents. In all, we have observations for 527 person and position combinations or 383 persons. For these appointees, we reconstruct their affiliations and employment history in the two years before and after their government service and the exact dates of announcements of political and corporate appointments. In particular, we are interested in connections to listed firms for our event study. We consider only official firm connections, namely corporate executives, members of the board of directors and advisory boards and employees.

We perform an extensive full-text search via LexisNexis to collect this information. Thereby, we mainly draw on newswires, press releases, transcripts of press conferences and news papers for the announcement dates. Overall, we rely on over 7,000 individual documents (see

\footnotetext{
${ }^{28}$ FDCH Political Transcripts, "U.S. Senator John Warner (R-VA) holds hearing on Department of Defense nominations," May 10, 2001. Federal News Service, “Hearing of the Senate Armed Services Committee,” October 6, 2005.

${ }^{29}$ Defense Daily, "SASC changes ethics rules for top Pentagon officials," September 28, 2005. Defense Daily, "SECNAV Winter wins ethics waivers for work on Northrop Grumman issues,” March 24, 2006.

${ }^{30}$ Washington Post, “Army Secretary defends support from Enron,” April 5, 2002.

${ }^{31}$ Cited in Associated Press, “Fact check: Exceptions made to anti-lobbyist rule,” January 22, 2009.
} 
Table A1 in Appendix). In addition to these sources, we use the SEC-filings and Marquis Who's Who for affiliations and employment history. The SEC-filings proved to be especially important for the identification of board memberships. ${ }^{32}$

We need four types of daily stock market data for our analysis, whereby we rely in each case on Datastream. First, we gather daily stock prices for politically connected individual firms. Second, we employ national stock market indices for our market model. Thereby, we chose the S\&P 500 as our market index for the United States stock market. ${ }^{33}$ Third, we will later augment the market model by an industry index. Thereby, we use the ICB industry classification to identify firms' main source of revenue and download the corresponding industry index from Datastream. Finally, we rely on Datastream for daily stock market data on market capitalization and trading volume.

In order to isolate stock market reactions to announcements of political and corporate appointments, we control for market co-movement and exclude potentially confounded events. We purge stock returns from market-wide stock market developments using a standard market model (MacKinlay, 1997). Thereby, we first regress the returns of individual stocks on the returns of the relevant market index for an estimation window prior to the announcement day $\tau$.

$$
R_{i, t}=\alpha_{i}+\beta_{i} \cdot R_{m, t}+\varepsilon_{i, t} \text {, over } \mathrm{t}=\tau-280 \ldots \tau-29
$$

where $R_{i, t}$ and $R_{m, t}$ stand for daily returns of individual stock $i$ and market index $m$, respectively, and $t$ for trading days. Based on the resulting parameter estimates, we compute the daily abnormal return for the announcement day and the next day, $\tau$ and $\tau+1$, in the following way:

$$
A R_{i, t}=R_{i, t}-\hat{\alpha}_{i}-\hat{\beta}_{i} \cdot R_{m, t}
$$

We aggregate the abnormal returns in two dimensions. First, we estimate average abnormal returns across observations and corresponding standard errors. We report two different standard errors. One set of standard errors is computed using the residual variance from the market model of the estimation window. A second set of standard errors is based on the cross-

\footnotetext{
${ }^{32}$ In LexisNexis, the SEC-filings are available in electronic form for around 4000 U.S. firms since 1987 and for all listed U.S. firms since 1991. Furthermore, news paper and newswire coverage in LexisNexis is much more limited before the late 1980s. For these reasons, our analysis starts with the Bush Sr. administration.

${ }^{33}$ Non-U.S. listed firms represent about $10 \%$ of our observations for political appointments and private sector appointments, respectively. In these cases, we use the DAX30 for Germany, the CAC40 for France, Vienna Stock Exchange for Austria, the Amsterdam Stock Exchange All Shares for the Netherlands, the FTSE100 for the United Kingdom, the OMX Stockholm Benchmark for Sweden, the Singapore Straits Times Index for Singapore, the SMI for Switzerland, the Tel Aviv Stock Exchange for Israel and the S\&P/TSX for Canada.
} 
section variance of abnormal returns. The latter method accounts for variance inflation on the announcement day. Second, we report both one-day and two-day cumulative abnormal returns.

The event date $\tau$ is the day of the announcement in case the announcement was on a trading day before markets closed or the next trading day otherwise. Because it was not possible to determine the exact time of the announcement in all cases, we also estimate the two-day cumulative returns. In this way, we make sure to capture the stock market reactions to all announcements.

In a final, but important step, we want to make sure that our abnormal returns are not driven by confounding factors. We exclude observations from the analysis, if other important firmnews identified in a full-text search such as earnings and dividend announcements, share repurchases and M\&A activity were also announced on the announcement day. If such firmnews is released on the day after the announcement day, observations remain in the sample, but the two-day abnormal return is set equal to the (unconfounded) one-day abnormal return. We also drop illiquid stocks. ${ }^{34}$ Eliminating confounded and illiquid observations reduces our sample for political appointments from 95 to 85 and for corporate appointments from 109 to 85 observations. The higher number of confounded corporate announcements stems from the fact that board members are often announced during annual share holder meetings with the concurrent release of earnings and dividends. Online Appendix 1 provides detailed information on the all political and corporate announcements and their firm connections and Online Appendix 2 lists all positions at the Department of Defense considered for this study.

\section{Empirical Results for Political Appointments}

\subsection{Baseline Results and Robustness}

We start the discussion of our results by giving a picture of the revolving door of the Pentagon. Table 1 depicts the affiliations of all the appointees in our sample both before and after their current position at the Department of Defense. Two aspects are worth noting: First, the largest part of appointees comes from and remains in the Department of Defense. One explanation for this is that some appointees get nominated for other positions within the department, serve in an acting position or get promoted. Another reason is that career

\footnotetext{
${ }^{34}$ We compute a measure for daily liquidity based on Amihud (2002) and equation (1) in Karolyi et al. (2012) and drop the bottom 2 percent of the distribution for a time window of $+/-20$ days around political and corporate appointments. This price impact measure relates firm $i$ 's absolute return to its trading volume on a given day.
} 
bureaucrats are sometimes appointed to these top positions. This is also reflected by the large share of appointees whose ex ante and ex post affiliation is both the Department of Defense. ${ }^{35}$ Second, a substantial share of appointees comes from or goes to the private sector. The private sector accounts for nearly $21 \%$ of all affiliations held by appointees prior to their current position. Around $28 \%$ of appointees move to the industry after leaving their current position at the Department of Defense. Note that in case of nearly $16 \%$ of observations, there is no ex post affiliation for one out of three reasons. Appointees are marked as not applicable, if they have been nominated, but never took office, if they passed away during their tenure or if they are still in office.

We now turn to stock market reactions to political appointments. Panel A of Table 2 presents the results for the main sample of 85 observations. Firm ties to these political appointees are well established, with an average tenure at firms of around seven and a half years. ${ }^{36}$ We find positive abnormal returns of $0.82 \%$ for the announcement day and of $0.84 \%$ for a two-day window including the announcement day and the next trading day. Both estimates are statistically significant at conventional levels. One might be concerned that these results are driven by either important or noisier observations or by industry-wide stock market movements. Another potential concern is that an omitted variable could induce the positive correlation between stock returns and political appointments. To address these concerns, we report four robustness tests.

First, Panel B of Table 2 exhibits the average abnormal returns for a trimmed sample, excluding the top and bottom 5\% of the abnormal return distribution during the event windows. As can be seen, the point estimates are smaller, but statistically significant at least at the $95 \%$ level.

Second, Panel C of Table 2 presents average scaled abnormal returns, i.e., abnormal returns divided by the standard deviation of estimation period residuals. Thereby, abnormal returns of noisier observations receive less weight than more reliable ones. According to Kolari and Pynnönen (2010), scaled abnormal returns are a preferred signal detection device. At the same time, it is important to note that the point estimates are not informative about economic magnitude. The results remain statistically significant at conventional levels.

\footnotetext{
${ }^{35}$ Also included in this category is acting Army Secretary John W. Shannon, who was caught shoplifting a women's blouse and skirt at an Army post exchange but nevertheless got an USD 85,000-a-year consulting job at the Department of Defense (see, e.g., Washington Post, “Shannon checking Pentagon's inventory,” December $8,1993)$.

${ }^{36}$ Tenure does not seem to explain the variation in abnormal returns reported later on (see Online Appendix 3).
} 
Third, we control for market- and industry-wide stock market movements in Panel D of Table 2. Political appointees with an industry background might be expected to be more responsive to industry interests in general, without favoring a particular firm. For instance, the Wall Street Journal heralded the likely appointment of General Dynamic Corp. top executive Gordon England to Deputy Secretary of Defense as "good news for the defense industry.”37 Therefore, we augment the market model by an industry index, based on ICB's industries in Datastream. If we then found no positive abnormal returns, this would be consistent with industry-wide effects. The interpretation and implications of industry-wide effects are radically different from firm-specific effects. Only the latter can be interpreted in terms of conflicts of interest. The estimates are slightly smaller, but still positive and statistically significant.

Fourth, we conduct a placebo test in the spirit of Dube, Kaplan and Naidu (2011). We shift all political appointments backward by 30, 50, 70, 90, 110, 130 and 150 trading days and, then, generate for these placebo appointments the abnormal and cumulative abnormal returns as described in section 3. Note that shifting events forwards would be problematic in our context, since the estimation window for the placebo events would be confounded by the political appointment. ${ }^{38}$ Furthermore, the pooling of (up to seven) placebo appointments per observation has two advantages. First, we are conservative in the sense that the null hypothesis of no stock market reaction is more likely to be rejected. Second, instead of controlling for other important firm-news like earnings or dividend announcements, the high number of placebo events assures that any potential positive and negative confounding factors are likely to be cancelled out. The placebo estimates reported in Panel E of Table 2 are very small and not significantly different from zero for the one- or two-day window. This robustness check confirms our main finding that political appointments - and not unobserved firm-characteristics potentially correlated with political announcements - lead to positive abnormal returns.

Figure 1 displays kernel densities for the one-day abnormal returns for political appointments and for placebo appointments. While both distributions peak around zero, the return distribution for political appointments is flatter and modestly shifted to the right. This visual impression is also confirmed by a Kolmogorov-Smirnoff test, which rejects the equality of these two distributions at the 1 percent significance level.

\footnotetext{
${ }^{37}$ Wall Street Journal cited in The Frontrunner, "England expected to be nominated to fill Wolfowitz's post," March 30, 2005

${ }^{38}$ To be consistent with the baseline results, we drop placebo observations that are illiquid or fall within the 30 days before a political appointment.
} 
One might conjecture that the positive abnormal returns are rather associated with the departure of the (leaving) appointee from the firm than with her political appointment. Although this is theoretically possible, we deem it very implausible. Firing costs in the United States are low by international standards and anecdotal evidence suggests that it is much more likely that skilled people rather than "lemons" leave the firm for government. Top-positions at the Department of Defense are usually popular and subject to considerable prestige and competition. This should rather depress, not increase firms' stock prices. Furthermore, the successor is not made public on the same day as the announcement of the political appointment. In the following, we give two additional pieces of evidence that are inconsistent with this alternative interpretation of the abnormal returns.

First, we consider stock market reactions to news about withdrawals or deaths of political appointees. In such instances, strong expectations aroused by the nomination regarding the pending establishment of political connections are disappointed..$^{39}$ If the political connection is perceived as valuable, stock prices will be expected to fall on such negative news. It is quite rare that political appointees withdraw or are forced to withdraw their nomination due to political resistance in the Senate and it's even rarer that political appointees decease during their confirmation process or tenure. This is also reflected in our dataset. Still, there are some cases like for instance the designated Secretary of the Navy, Colin R. McMillan, who died before taking office, ${ }^{40}$ or the nomination of John G. Tower as the new Secretary of Defense on December 16, 1988. His nomination by President Bush Sr. was controversial. Both political parties had concerns about his intimate ties with the defense industry and his health. ${ }^{41}$ There were also allegations that he had been a womanizer with a drinking problem. ${ }^{42}$ His confirmation was rejected by the Senate with 53-47 votes - the first rejection of the confirmation of a cabinet member in 30 years. $^{43}$ The following results have to be interpreted with some caution due to the small number of (unconfounded) observations. Based on 13 observations, we find negative abnormal returns of $-0.52 \%$ for the announcement day and of $-0.93 \%$ for a two-day window (see Table 3, Panel B). Even though these estimates are not

\footnotetext{
${ }^{39}$ Note that some of these withdrawals are largely expected, while others are surprising.

${ }^{40}$ Associated Press, “Colin McMillan, Nominee for Navy Secretary, Dies at Age 67,” July 24, 2003.

${ }^{41}$ Washington Post, "FBI Undertakes Exhaustive Check on Tower; Probe of Former Senator for Defense Post May be the Most Thorough Done by Agency,” December 11, 1988. Associated Press, “Tower in Fair Condition After Polyp Surgery,” January 6, 1989.

42 Aerospace Daily, “Tower Nomination Poses Problems for Senate Committee,” February 1, 1989. Associated Press, "Panel Vote on Tower Expected Next Week Despite New Allegations," February 3, 1989.

${ }^{43}$ New York Times, "Senate Rejects Tower, 53-47; First Cabinet Veto since `59; Bush Confers on New Choice,” March 10, 1989.
} 
statistically significant, it is reassuring that the effect goes in the right direction and is of a similar magnitude.

Second, we assess whether political appointments also lead to positive abnormal returns in cases where the appointee is no longer officially associated with the firm? This implies that financial markets are able to price in the consequences of her departure of the firm and later on (within two years) the news about the political appointment. Gordon R. England constitutes a good example in this regard. His tenure with General Dynamics Corp. has lasted for nearly two decades, when he retired as Executive Vice President and his successor was announced a few weeks before his nomination as Secretary of the Navy. Panel C of Table 3 reports the announcement effects with and without "active” firm connections. For the later group, we find - based on 19 observations with an average tenure of nine and a half years positive and significant abnormal returns of $0.93 \%$ for the announcement day. While abnormal returns are not significant for a two-day window, the announcement effects for both groups are similar in magnitude.

\subsection{Further Results for Subsamples}

The overall effects in Table 2 may hide informative heterogeneity across subgroups. Therefore, Table 4 presents the results for four sample splits, whereby Panel A reproduces the baseline result from Table 2 for comparability. First, according to Panel B stock markets react more strongly to the political appointment of former board members than to other candidates.

Second, we find larger effects for political appointments to top-position at the Department of Defense. To split samples, we use pay-grades of the executive schedule and code as a "Top pay-grades” the two highest pay-grades. This includes the Secretary of Defense, his deputy, the service secretaries, and the Under Secretary of Defense (Acquisition, Technology, and Logistics). "Other high pay-grades” includes the third and fourth highest level of pay-grades, i.e., all other Senate confirmed appointees. The results suggest that investors expect political connections to top officials at the Pentagon to be more valuable.

Third, stock markets react more strongly to political appointments by Democratic than Republican administrations on the announcement day. This is consistent with the view expressed by Goldman et al. (2009) that there is a limited supply of political connections, which is especially limited in Democratic administrations. As can be seen from Table 4, there are fewer events related to Democrats.

Fourth, not all announcements were equally surprising. For example, Secretary of Defense Richard Cheney was probed in a press conference in 1989 about rumors about his choice of 
service secretaries more than a week before the official announcement. He virtually confirmed these rumors by saying that they were based on "good sources". ${ }^{44}$ We distinguish between two different levels of anticipation. We code as "Higher anticipation" all events for which the - later appointed - person but nobody else was rumored to be the candidate for this particular position. In contrast to that, "Lower anticipation" captures all other events. The latter announcements entail a higher surprise-content and, hence, are expected to lead to stronger stock market reactions. This is indeed what we find. Point estimates for largely unexpected political appointments are substantially larger and amount to $1.20 \%$ and $1.40 \%$ for the oneand two-day event window.

Figure 2 compares the kernel densities for the one-day abnormal returns for political appointments of "lower anticipation” with the placebo appointments. The distribution for more surprising political appointments is peaking at a positive abnormal return of around 1 percent and is slightly skewed to the right. The Kolmogorov-Smirnoff test rejects the equality of these two distributions at the 1 percent significance level.

In Table 5, we look again at the subgroups, but this time in a multivariate setting. For both event-windows, top-pay grades and the extent to which announcements are anticipated play a role. There is also some evidence that being nominated by the Democratic party has some significant explanatory power on the announcement day, but having been a board member does not come out significantly, conditional on the other characteristics. Given the relatively small number of observations, these results need to be interpreted with some caution. ${ }^{45}$

All our results so far refer to one- and two-day average cumulative abnormal returns. We expect financial markets to immediately price in important firm news. The motivation for two-day average cumulative abnormal returns mainly stems from the fact that it is sometimes uncertain, whether the appointment became public before or after trading closed on a given day. Over longer time horizons, the identifying assumption that markets only react to the announcements of political appointments and not to other news becomes more tenuous. Nevertheless, in Figure 3, we examine the temporal pattern of average cumulative abnormal returns for the four trading weeks prior to and after the announcement day, whereby the shaded area represents the two-day event window. We deal with confounding factors as described in section 3 and use all 85 observations of our baseline sample as well as the 39 less anticipated events. In order to facilitate comparability with the results presented in Tables 2

\footnotetext{
${ }^{44}$ Washington Post, "Cheney Believes Gorbachev Sincere; But Defense Chief Says Cutting West's Forces Would Be Premature,” April 5, 1989.

${ }^{45}$ Online Appendix 3 presents further results in a multivariate setting. In short, augmenting the parsimonious model with firm tenure, firm size or war times does not add further insights into the cross-sectional variation.
} 
and 4, we normalize the average cumulative abnormal returns so that they are zero on the day before the announcement date.

Although there is some variation over time, Figure 3 shows two important findings. First, cumulative abnormal returns are on average around one and two percentage points higher in the period after the event compared to the period before the event for the baseline sample and the sample of less anticipated events, respectively. Second, our one- and two-day average cumulative abnormal returns are comparable to longer-term effects. The remaining variation in the time-series could be explained in the following ways. There remains some uncertainty about the exact timing of other important firm news and, hence, some of these events may still confound the estimates. Further, we obviously cannot reconstruct the full information set of investors. Finally, some of the price movements may be related to political appointments. On the one hand, rumors regarding pending nominations may be reflected in the price movements of the baseline sample before the event date. For example, sources close to the transition team were cited on day -18 that Paul D. Wolfowitz's nomination as Deputy Secretary of Defense was likely. ${ }^{46}$ On the other hand, price movements after the event date may reflect uncertainties in the confirmation process. For example, William J. Lynn's nomination met resistance in the Senate on day +10 and has been temporarily stalled. ${ }^{47}$

\section{Empirical Results for Corporate Appointments}

We now turn to the results of private sector appointments of (former) political appointees and look at the other side of the revolving door. In Panel A of Table 6, we report the baseline results. We also find positive abnormal returns for the one- and two-day event window between $0.79 \%$ and $1.05 \%$, even though only significant at the 10 percent level. To compare the magnitudes of abnormal returns for corporate appointments with the respective magnitudes for political appointments, it is worth stressing that virtually all private sector appointments are unanticipated. Thus, the abnormal returns for comparative purposes are in Table 4, Panel E, “Lower anticipation” amounting to $1.20 \%$ and $1.40 \%$, respectively. Generally speaking, our results for corporate appointments are slightly lower and less statistically significant than the results for political appointments. Panel B to Panel E presents the same robustness checks as reported in Table 2. The results for corporate appointments are largely similar to the baseline results. One exception is the results for the trimmed sample,

\footnotetext{
${ }^{46}$ United Press International, “Wolfowitz Tipped for Pentagon’s No. 2,” January 10, 2001.

${ }^{47}$ Associated Press Financial Wire, “Pentagon Nomination Stalls Amid Lobbying Concerns,” January 23, 2009. Associated Press, “McCain Disappointed by Ethics Waiver,” January 23, 2009.
} 
which fall below conventional levels of statistical significance for one method of calculating the standard errors. This suggests that the results for corporate appointments rest to a certain degree on outlier observations.

Figure 4 displays kernel densities for the one-day abnormal returns for corporate appointments of former political appointees and for placebo appointments. The return distribution for corporate appointments is flatter and the right site of the distribution is shifted outward. The Kolmogorov-Smirnoff test rejects the equality of these two distributions at the 5 percent significance level.

Table 7 deals with the results for the different subgroups. Once more, Panel A of Table 7 replicates the baseline results for private sector appointments. According to Panel B of Table 7, we find larger positive abnormal returns for corporate board appointments than for other corporate appointments. The two-day event window abnormal returns for board members can be directly compared to the results of Goldman et al. (2009). They estimate an abnormal return of $0.69 \%$ as compared to $1.29 \%$ in our case. Thus, the estimates are in the same ballpark.

We find no evidence that corporate appointments of former top officials have larger effects. Consistent with our results for political appointments and with results from Goldman et al. (2009), we find stronger effects for people that served in Democratic administrations. ${ }^{48}$

\section{Conclusions}

All our results point in the same direction. Investors expect firms to profit from their political connections to appointees. In particular, we find positive abnormal average returns of about between $0.82 \%$ and $0.84 \%$ for the one- and two-day event window in case of political appointments. These main results are insensitive to a number of robustness checks. Furthermore, these results for the overall sample are a lower bound of the true value of firm connection, because some of the appointments are largely anticipated. Restricting the sample to largely unexpected events, the average abnormal returns amount to between $1.20 \%$ and $1.40 \%$. Similarly, in case of corporate appointments there are also positive, but smaller and less robust, positive abnormal returns between $0.79 \%$ and $1.05 \%$ for the one- and two-day event window.

\footnotetext{
${ }^{48}$ For the sake of brevity and lack of robust results, we do not report the multivariate analysis for corporate appointments in the main text. There is some weak evidence that hiring a former political appointee is better news for smaller firms (see Online Appendix 4).
} 
It is important to keep in mind that these stock market reactions reflect expectations of investors. Thus, this is obviously no proof for any wrong-doing of individual political appointees during their tenure for two reasons. First, expectations need not to realize in individual cases even if they are accurate on average. Second, our empirical strategy does not allow us to pin down one particular reason for why firms are expected to profit. However, it is hard to think of other reasons for higher expected returns than conflicts of interest. In the best case, conflicts of interest distort procurement contract award competitions, because some firms have informational advantages. In the worst case, decisions are tilted towards specific firms and against the interest of taxpayers and the armed forces.

We find evidence consistent with conflicts of interest despite a generally strong institutional environment in the United States with checks and balances and a free media as well as specific institutional safeguards. However, our results do not necessarily suggest that the benefits of more regulation outweigh the costs. According to Gansler (2011), the tight net of regulation currently in place already entails enormous compliance costs for both the Department of Defense and the industry. Furthermore, our results do not allow for an overall assessment of the costs and benefits of political appointments from the private sector. Although our results highlight one important cost, they are silent about potential benefits.

In our view, an important area for future research is to identify the channels through which firms profit from their connections to political appointees in office. Given the enormous volume of procurement contracts in the Department of Defense, one might expect preferential treatment in procurement decisions to be one important channel. A natural starting point would, therefore, be to look at the effect of political appointments on the volume or growth of procurement contracts (analogous to the study of Goldman et al., 2009, for corporate appointments). Yet, as we outlined above, other channels are likely to be important as well. Therefore, it might be instructive to investigate an agency with mainly regulatory competencies. 


\section{References:}

Acemoglu, Daron, Simon Johnson, Amir Kermani, James Kwak, and Todd Mitton (2010), "The value of political connections in the United States," mimeo, Harvard University.

Agrawal, Anup and Charles Knoebel (2001), "Do some outside directors play a political role?” Journal of Law and Economics, Vol. 44, pp. 179-198.

Amihud, Yakov (2002), "Illiquidity and stock returns: Cross-section and time-series effects," Journal of Financial Markets, Vol. 5, pp. 31-56.

Bechtel, Michael and Gerald Schneider (2010), "Eliciting substance from 'hot air': Financial market responses to EU summit decisions on European defense," International Organization, Vol. 64, pp. 199-223.

Bertrand, Marianne, Matilde Bombardini, and Francesco Trebbi (2011), "Is it whom you know or what you know? An empirical assessment of the lobbying process," mimeo, Chicago Booth.

Bertrand, Marianne, Francis Kramarz, Antoinette Schoar and David Thesmar (2007), "Politically connected CEOs and corporate outcomes: Evidence from France," mimeo, CREST.

Blanes i Vidal, Jordi, Mirko Draca, and Christian Fons-Rosen (2012), "Revolving door lobbyists,” American Economic Review, forthcoming.

Borisov, Alexander, Eitan Goldman, and Nandini Gupta (2011), “The value of (corrupt) lobbying,” mimeo, Indiana University.

Bunkanwanicha, Pramuan and Yupana Wiwattanakantang (2009), "Big business owners in politics,” Review of Financial Studies, Vol. 22, pp. 2133-2168.

Cameron, Colin and Pravin Trivedi (2005), "Microeconometrics: Methods and Applications,” Cambridge University Press.

Claessens, Stijn, Eric Feijen, and Luc Laeven (2008), "Political connections and preferential access to finance: The role of campaign contributions," Journal of Financial Economics, Vol. 88, pp. 554-580.

Cooper, Michael, Huseyin Gulen, and Alexei Ovtchinnikov (2010), "Corporate political contributions and stock returns,” Journal of Finance, Vol. 65, pp. 687-724.

Department of Defense (2004), "Department of Defense key officials (1947-2004)," Historical Office, Office of the Secretary of Defense.

Dube, Arindrajit, Ethan Kaplan and Suresh Naidu (2011), “Coups, corporations, and classified information,” Quarterly Journal of Economics, Vol. 126, pp. 1375-1409.

Faccio, Mara (2006), "Polically connected firms,” American Economic Review, Vol. 96, pp. 369-386.

Faccio, Mara and David Parsley (2009), "Sudden deaths: Taking stock of geographic ties," Journal of Financial and Quantitative Analysis, Vol. 44, pp. 683-718.

Faccio, Mara, Ronald Masulis, and John McConnell (2006), "Political connections and corporate bailouts,” Journal of Finance, Vol. 61, pp. 2597-2635.

Ferguson, Thomas and Hans-Joachim Voth (2008), "Betting on Hitler - The value of political connections in Nazi Germany,” Quarterly Journal of Economics, Vol. 123, pp. 101-137.

Fisman, Raymond (2001), "Estimating the value of political connections," American Economic Review, Vol. 91, pp. 1095-1102. 
Fisman, David, Ray Fisman, Julia Galef, and Rakesh Khurana (2006), "Estimating the value of connections to Vice-president Cheney,” mimeo, Columbia University.

Gansler, Jacques (2011), “Democracy’s arsenal: Creating a twenty-first-century defense industry," MIT Press.

Goldman, Eitan, Jörg Rocholl, and Jongsil So (2009), “Do politically connected boards affect firm value?” Review of Financial Studies, Vol. 22, pp. 2332-2360.

Goldman, Eitan, Jörg Rocholl, and Jongsil So (2010), "Political connections and the allocation of procurement contracts,” mimeo, Indiana University.

Government Printing Office (various years), "United States government policy and supporting positions (Plum Book),” Government Printing Office.

Huber, John and Nolan McCarty (2004), "Bureaucratic Capacity, Delegation, and Political Reform,” American Political Science Review, Vol. 98, pp. 481-494.

Huber, Jürgen and Michael Kirchler (2012), “Corporate campaign contributions and abnormal stock returns after presidential elections,” Public Choice, forthcoming.

Jayachandran, Seema (2006), “The Jeffords effect,” Journal of Law and Economics, Vol. 49, pp. 397-425.

Johnson, Simon and Todd Mitton (2003), "Cronyism and capital controls: Evidence from Malaysia,” Journal of Financial Economics, Vol. 67, pp. 351-382.

Karolyi, Andrew, Kuan-Hui Lee and Mathijs van Djik (2012), "Understanding commonality in liquidity around the world,” Journal of Financial Economics, Vol. 105, pp. 82-112.

Karpoff, Jonathan, Scott Lee and Valaria Vendrzyk (1999), "Defense procurement fraud, penalties, and contractor influence,” Journal of Political Economy, Vol. 107, pp. 809-842.

Knight, Brian (2006), “Are policy platforms capitalized into equity prices? Evidence from the Bush/Gore 2000 Presidential election,” Journal of Public Economics, Vol. 90, pp. 751773.

Khwaja, Asif and Atif Mian (2005), "Do lenders favor politically connected firms? Rent provision in an emerging financial market," Quarterly Journal of Economics, Vol. 120, pp. 1371-1411.

Kovacic, William and Dennis Smallwood (1994), "Competition policy, rivalvries, and defense industry consolidation,” Journal of Economic Perspectives, Vol. 8, pp. 91-110.

Kolari, James and Seppo Pynnönen (2010), "Event study testing with cross-sectional correlation of abnormal returns,” Review of Financial Studies, Vol. 23, pp. 3996-4025.

Leuz, Christian and Felix Oberholzer-Gee (2006), "Political relationships, global financing, and corporate transparency: Evidence from Indonesia," Journal of Financial Economics, Vol. 81, pp. 411-439.

Lewis, David (2008), “The politics of Presidential appointments: Political control and bureaucratic performance,” Princeton University Press.

Lichtenberg, Frank (1989), “How elastic is the government's demand for weapons?” Journal of Public Economics, Vol. 40, pp. 57-78.

Mackenzie, Calvin (1987), “'If you want to play, you've got to pay:' Ethics regulation and the Presidential appointments system, 1964-1984,” pp. 77-99, in: Mackenzie, Calvin (ed.), "The in-and-outers: Presidential appointees and transient government in Washington," John Hopkins University Press. 
MacKinlay, Craig (1997), "Event studies in economics and finance,” Journal of Economic Literature, Vol. 35, pp. 13-39.

Rasor, Dina and Robert Baumann (2007), "Betraying our troops: The destructive results of privatizing war,” Palgrave Macmillan.

Roberts, Brian (1990), “A dead Senator tells no lies: Seniority and the distribution of federal benefits,” American Journal of Political Science, Vol. 34, pp. 31-58.

Rogerson, William (1989), "Profit regulation of defense contractors and prizes for innovation,” Journal of Political Economy, Vol. 97, pp. 1284-1305.

Rogerson, William (1994), "Economic incentives and the defense procurement process," Journal of Economic Perspectives, Vol. 8, pp. 65-90.

Silverman, Bernard (1986), “Density Estimation for Statistics and Data Analysis,” Chapman and Hall.

Snowberg, Eric, Justin Wolfers, and Eric Zitzewitz (2007), "Partisan impacts on the economy: Evidence from prediction markets and close elections," Quarterly Journal of Economics, Vol. 122, pp. 807-829. 


\section{Table 1. The revolving door of the Pentagon: Political appointees' affiliations before/after current position}

\begin{tabular}{lccllr}
\hline $\begin{array}{l}\text { Panel A: Type of affiliations ex ante and } \\
\text { ex post }\end{array}$ & \multicolumn{3}{l}{ Panel B: Most common ex ante/ex post-combinations } \\
\hline Type of affiliation & Ex ante & Ex post & Type of affiliation ex ante & Type of affiliation ex post \\
\hline Public sector general & 10.96 & 7.17 & Dpt. of Defense & Dpt. of Defense & 19.80 \\
Dpt. of Defense & 46.30 & 30.04 & Dpt. of Defense & Private sector general & 7.64 \\
U.S. Congress & 9.19 & 0.92 & Dpt. of Defense & NPO, think tank, academia & 4.76 \\
NPO, think tank, academia & 11.75 & 13.21 & Dpt. of Defense & Not applicable & 4.33 \\
Private sector general & 13.69 & 17.23 & Dpt. of Defense & Law and consulting firms & 4.16 \\
Law and consulting firms & 6.97 & 11.12 & Private sector general & Private sector general & 3.63 \\
Not known & 1.14 & 4.74 & NPO, think tank, academia & Not applicable & 3.49 \\
Not applicable & - & 15.56 & Other & & 52.19 \\
\hline \hline
\end{tabular}

Notes: All figures are in percent. The table reports affiliations of the 527 person/position-observations or 383 persons in our sample. Affiliations refer to all positions held two years prior to the announcement (ex ante) and two years after leaving the position (ex post). Multiple affiliations are possible; in this table, observations are weighted by the inverse of the number of affiliations per observation. If a person changes positions within the Dpt. of Defense, outside affiliations ex ante are recorded for the first position, outside affiliations ex post for the last position in order to avoid double counting. "Not applicable" is used for persons who were nominated only, who died while in office or incumbents. 


\section{Table 2. Baseline for the announcement effect of political appointments to the U.S. department of defense ("ex ante")

$\begin{array}{ccc}\begin{array}{c}\text { Number } \\ \text { of Obs. }\end{array} & \text { Abnormal Return } & \text { Cumulative Abnormal } \\ & (\%):[0] & \text { Return }(\%):[0,+1]\end{array}$

Panel A: Baseline

\begin{tabular}{|c|c|c|c|}
\hline All appointees & 85 & $\begin{array}{l}0.82 \\
(0.27)^{* * *} \\
{[0.21]^{* * *}} \\
\end{array}$ & $\begin{array}{c}0.84 \\
(0.39)^{* *} \\
{[0.31]^{* * *}}\end{array}$ \\
\hline \multicolumn{4}{|c|}{ Panel B: Robustness - Trimmed sample } \\
\hline All appointees & 77 & $\begin{array}{l}0.68 \\
(0.26)^{* *} \\
{[0.14]^{* * *}}\end{array}$ & $\begin{array}{c}0.58 \\
(0.36)^{* *} \\
{[0.19]^{* * *}}\end{array}$ \\
\hline
\end{tabular}

Panel C: Robustness - Scaled abnormal returns

\begin{tabular}{|c|c|c|c|}
\hline All appointees & 85 & $\begin{array}{c}0.32 \\
(0.11)^{* * *} \\
{[0.10]^{* * *}}\end{array}$ & $\begin{array}{l}0.21 \\
(0.11)^{*} \\
{[0.09]^{* *}}\end{array}$ \\
\hline
\end{tabular}

Panel D: Robustness - Market model augmented by industry index

\begin{tabular}{|c|c|c|c|}
\hline All appointees & 85 & $\begin{array}{l}0.69 \\
(0.27)^{* *} \\
{[0.20]^{* * *}}\end{array}$ & $\begin{array}{l}0.71 \\
(0.37)^{*} \\
{[0.28]^{* *}}\end{array}$ \\
\hline
\end{tabular}

Panel E: Robustness - Time-shifted placebos

\begin{tabular}{llll}
\hline & & -0.02 & 0.09 \\
Placebo events & \multirow{2}{*}{563} & $(0.11)$ & $(0.16)$ \\
& & {$[0.10]$} & {$[0.14]$} \\
\hline \hline
\end{tabular}

Notes: The sample is based on political appointments to the U.S. Department of Defense in the years 1988 to 2009. Abnormal returns relate to the announcements of nominations of political appointees who were serving within the last two years as a member of board of directors or advisory board, an executive officer or an employee for a listed firm. Announcement dates and prior affiliations to listed firms are gathered on the basis of a full-text search on LexisNexis and SEC-filings. This yields 95 observations. Observations are excluded, i) if they are confounded by other important firm-news (such as earnings and dividend announcements, share repurchases and M\&A activity on the announcement day), ii) if their underlying stock is illiquid or if iii) the announcement falls in the first trading week after September 11 in 2001. The resulting baseline sample consists of 85 observations. Abnormal Returns (ARs) and Cumulative Abnormal Returns (CARs) are based on a market model, whereby for example S\&P 500, CAC 40 and DAX 30 is used as the measure of market returns for United States, France and Germany, respectively. Standard errors in parenthesis are calculated on the basis of the standard deviation of estimation-period residuals. Standard errors in brackets are computed using the crosssection standard deviation of ARs and CARs, respectively, and account for variance inflation at the announcement day. Panel A reports the baseline results ("ex ante") and the remaining panels offer different robustness checks to the baseline. Panel B displays results for average ARs and CARs, where the top and bottom 5\% are dropped. Panel C shows results for average scaled AR and CAR, i.e., AR and CAR divided by regression residual standard deviation of the estimation period. Here, standard errors in parenthesis are computed using the variance of scaled abnormal returns under the assumption of no-event induced variance, which is $(T-p-1) /(T-p-3)$, where $T$ and $p$ are the length of the estimation window and the number of explanatory variables in the market model. Standard errors in brackets are again calculated using the crosssection standard deviation of scaled ARs and scaled CARs to account for variance inflation at the announcement day. Panel D augments one factor market model by including Datastream industry index for the respective company in addition to market model (10 different industries based on ICB-classification). Panel E generates for each appointee-firm observation placebo announcements dates, which are 30, 50, 70, 90, 110, 130 and 150 days prior to the true announcement date. For these placebo events ARs and CARs are computed in the same way as before and reported in this panel. ${ }^{* * *},{ }^{* *}, *$ denote statistical significance at the $1 \%, 5 \%$ and $10 \%$ levels, respectively. 


\section{Table 3. Corroborating evidence for the announcement effect of political appointments to the U.S. department of defense ("ex ante")}

Number

of Obs.

Panel A: Baseline

\begin{tabular}{|c|c|c|c|}
\hline All appointees & 85 & $\begin{array}{l}0.82 \\
(0.27)^{* * *} \\
{[0.21]^{* * *}}\end{array}$ & $\begin{array}{l}0.84 \\
(0.39)^{* *} \\
{[0.31]^{* * *}}\end{array}$ \\
\hline \multicolumn{4}{|c|}{ Panel B: Withdrawals } \\
\hline Withdrawals & 13 & $\begin{array}{l}-0.52 \\
(0.68) \\
{[0.43]}\end{array}$ & $\begin{array}{l}-0.93 \\
(0.96) \\
{[0.69]}\end{array}$ \\
\hline
\end{tabular}

Panel C: Status of firm connection

\begin{tabular}{lccc}
\hline \multirow{3}{*}{ No active connection } & \multirow{2}{*}{19} & 0.93 & 0.74 \\
& & $(0.50)^{*}$ & $(0.70)$ \\
& & {$[0.36]^{* *}$} & {$[0.46]$} \\
Active connection & \multirow{2}{*}{66} & 0.78 & 0.87 \\
& & $(0.32)^{* *}$ & $(0.46)^{*}$ \\
& & {$[0.26]^{* * *}$} & {$[0.37]^{* *}$} \\
\hline \hline
\end{tabular}

Notes: The sample is based on political appointments to the U.S. Department of Defense in the years 1988 to 2009. Abnormal returns relate to the announcements of nominations, withdrawals in the confirmation process or deaths of political appointees who were serving within the last two years as a member of board of directors or advisory board, an executive officer or an employee for a listed firm. Announcement dates and prior affiliations to listed firms are gathered on the basis of a full-text search on LexisNexis and SEC-filings (for further details see Table 2). Standard errors in parenthesis are calculated on the basis of the standard deviation of estimationperiod residuals. Standard errors in brackets are computed using the cross-section standard deviation of ARs and CARs, respectively, and account for variance inflation at the announcement day. Panel A reproduces the baseline results ("ex ante”) from Table 2 for comparability and the remaining panels offer various sample splits. Panel B shows results for the announcement effect of individuals, whose appointment has been withdrawn during the confirmation process or who have died during this process or their tenure. Panel $\mathrm{C}$ distinguishes between those political appointments, where the political appointee was still associated with the firm at the time of the political appointment, and those without such an active firm connection. ***, **, * denote statistical significance at the $1 \%, 5 \%$ and $10 \%$ levels, respectively. 


\section{Table 4. Subsamples of the announcement effect of political appointments to the U.S. department of defense ("ex ante")}

Number

Abnormal Return

Cumulative Abnormal Return

of Obs.

(\%): [0]

$(\%):[0,+1]$

\section{Panel A: Baseline}

\begin{tabular}{|c|c|c|c|}
\hline All appointees & 85 & $\begin{array}{l}0.82 \\
(0.27)^{* * *} \\
{[0.21]^{* * *}}\end{array}$ & $\begin{array}{l}0.84 \\
(0.39)^{* *} \\
{[0.31]^{* * *}}\end{array}$ \\
\hline \multicolumn{4}{|c|}{ Panel B: Subsamples - Firm position } \\
\hline Board member & 52 & $\begin{array}{l}0.93 \\
(0.36)^{* *} \\
{[0.29]^{* * *}}\end{array}$ & $\begin{array}{l}1.26 \\
(0.51)^{* *} \\
{[0.44]^{* * *}}\end{array}$ \\
\hline Non-board member & 33 & $\begin{array}{l}0.63 \\
(0.41) \\
{[0.31]^{* *}}\end{array}$ & $\begin{array}{c}0.17 \\
(0.58) \\
{[0.35]}\end{array}$ \\
\hline
\end{tabular}

Panel C: Subsamples - Position at the defense department

\begin{tabular}{lccc}
\hline \multirow{3}{*}{ Top pay-grades } & \multirow{2}{*}{46} & 1.18 & 1.36 \\
& & $(0.38)^{* * *}$ & $(0.53)^{* * *}$ \\
& & {$[0.31]^{* * *}$} & {$[0.45]^{* * *}$} \\
Other high pay-grades & \multirow{2}{*}{39} & 0.39 & 0.23 \\
& & $(0.40)$ & $(0.57)$ \\
\hline
\end{tabular}

Panel D: Subsamples - Party of nomination

\begin{tabular}{|c|c|c|c|}
\hline \multirow{3}{*}{ Democratic } & \multirow{3}{*}{34} & 1.00 & 0.74 \\
\hline & & $(0.42)^{* *}$ & $(0.59)$ \\
\hline & & {$[0.31]^{* * *}$} & {$[0.40] *$} \\
\hline \multirow{3}{*}{ Republican } & \multirow{3}{*}{51} & 0.69 & 0.91 \\
\hline & & $(0.36)^{*}$ & $(0.51)^{*}$ \\
\hline & & {$[0.29] * *$} & {$[0.44]^{* *}$} \\
\hline
\end{tabular}

Panel E: Subsamples - Anticipation

\begin{tabular}{lccc}
\hline & & 1.20 & 1.40 \\
Lower anticipation & \multirow{2}{*}{39} & $(0.43)^{* * *}$ & $(0.61)^{* *}$ \\
& & {$[0.35]^{* * *}$} & {$[0.49]^{* * *}$} \\
Higher anticipation & \multirow{3}{*}{46} & 0.49 & 0.37 \\
& & {$[0.35)$} & $(0.50)$ \\
\hline \hline
\end{tabular}

Notes: The sample is based on political appointments to the U.S. Department of Defense in the years 1988 to 2009. Abnormal returns relate to the announcements of nominations of political appointees who were serving within the last two years as a member of board of directors or advisory board, an executive officer or an employee for a listed firm. Announcement dates and prior affiliations to listed firms are gathered on the basis of a full-text search on LexisNexis and SEC-filings (for further details see Table 2). Standard errors in parenthesis are calculated on the basis of the standard deviation of estimation-period residuals. Standard errors in brackets are computed using the cross-section standard deviation of ARs and CARs, respectively, and account for variance inflation at the announcement day. Panel A reproduces the baseline results ("ex ante") from Table 2 for comparability and the remaining panels offer various sample splits. Panel B shows results for individuals being aligned to firm as a board member or in another position. Panel $\mathrm{C}$ distinguishes between the top two paygrades and the next two highest levels of pay-grades in federal government. Panel D offers insights into the nominating party. Panel E differentiates between at least partly unanticipated ("Lower anticipation”) and largely anticipated announcements of political appointees ("Higher anticipation”). ***, **, * denote statistical significance at the $1 \%, 5 \%$ and $10 \%$ levels, respectively. 


\section{Table 5. Multivariate analysis of announcement effect of political}

appointments to the U.S. department of defense ("ex ante")

Abnormal Return

(\%): [0]

Board member

0.05

$(0.41)$

$0.90 * *$

$(0.41)$

$0.81^{*}$

$(0.46)$

$1.14 * *$

Lower anticipation

$-0.55$

Constant
Cumulative Abnormal Return

(\%): $[0,+1]$

0.77

$(0.58)$

0.98*

(0.56)

0.53

(0.73)

1.34*

(0.73)

$-0.99$

(0.76)

85

Number of Obs.

85

0.10

R-squared

0.12

Notes: The sample is based on political appointments to the U.S. Department of Defense in the years 1988 to 2009. Abnormal returns relate to the announcements of political appointees who were serving within the last two years as a member of board of directors or advisory board, an executive officer or an employee for a listed firm. Announcement dates and prior affiliations to listed firms are gathered on the basis of a full-text search on LexisNexis and SEC-filings (for further details see Tables 2 and 4). Standard errors reported in parenthesis are based on 1000 bootstraps. ${ }^{* * *},{ }^{* *},{ }^{*}$ denote statistical significance at the $1 \%, 5 \%$ and $10 \%$ levels, respectively. 


\section{Table 6. Baseline for the announcement effect of private sector appointments of (former) political appointees (“ex post”)

$\begin{array}{ccc}\begin{array}{c}\text { Number } \\ \text { of Obs. }\end{array} & \text { Abnormal Return } & \text { Cumulative Abnormal } \\ & (\%):[0] & \text { Return }(\%):[0,+1]\end{array}$

Panel A: Baseline

\begin{tabular}{|c|c|c|c|}
\hline All appointees & 85 & $\begin{array}{c}0.79 \\
(0.40)^{*} \\
{[0.46]^{*}} \\
\end{array}$ & $\begin{array}{l}1.05 \\
(0.57)^{*} \\
{[0.50]^{* *}}\end{array}$ \\
\hline \multicolumn{4}{|c|}{ Panel B: Robustness - Trimmed sample } \\
\hline All appointees & 77 & $\begin{array}{l}0.49 \\
(0.40) \\
{[0.23]^{* *}}\end{array}$ & $\begin{array}{l}0.66 \\
(0.49) \\
{[0.26]^{* * *}}\end{array}$ \\
\hline
\end{tabular}

Panel C: Robustness - Scaled abnormal returns

\begin{tabular}{|c|c|c|c|}
\hline All appointees & 85 & $\begin{array}{l}0.22 \\
(0.11)^{* *} \\
{[0.13]^{*}}\end{array}$ & $\begin{array}{l}0.22 \\
(0.11)^{* *} \\
{[0.10]^{* *}}\end{array}$ \\
\hline
\end{tabular}

Panel D: Robustness - Market model augmented by industry index

\begin{tabular}{|c|c|c|c|}
\hline All appointees & 85 & $\begin{array}{c}0.78 \\
(0.40)^{*} \\
{[0.45]^{*}}\end{array}$ & $\begin{array}{l}1.04 \\
(0.56)^{*} \\
{[0.49]^{* *}}\end{array}$ \\
\hline
\end{tabular}

Panel E: Robustness - Time-shifted placebos

\begin{tabular}{|c|c|c|c|}
\hline Placebo events & 586 & $\begin{array}{c}0.09 \\
(0.15) \\
{[0.17]}\end{array}$ & $\begin{array}{c}0.03 \\
(0.21) \\
{[0.33]}\end{array}$ \\
\hline
\end{tabular}

Notes: The sample is based on appointments to the private sector of (former) political appointees to the U.S. Department of Defense in the years 1989 to 2011. Abnormal returns relate to the announcements of (former) political appointees who were working (at least some time) for the U.S. Department of Defense during the last two years before their move to the private sector. Announcement dates and affiliations to listed firms are gathered on the basis of a full-text search on LexisNexis and SEC-filings. This yields 109 observations. Observations are excluded, i) if they are confounded by other important firm-news (such as earnings and dividend announcements, share repurchases and M\&A activity on the announcement day), ii) if their underlying stock is illiquid or if iii) the announcement falls in the first trading week after September 11 in 2001 . The resulting baseline sample consists of 85 observations. Abnormal Returns (ARs) and Cumulative Abnormal Returns (CARs) are based on a market model, whereby for example S\&P 500, CAC 40 and DAX 30 is used as the measure of market returns for United States, France and Germany, respectively. Standard errors in parenthesis are calculated on the basis of the standard deviation of estimation-period residuals. Standard errors in brackets are computed using the cross-section standard deviation of ARs and CARs, respectively, and account for variance inflation at the announcement day. Panel A reports the baseline results ("ex post”) and the remaining panels offer different robustness checks to the baseline. Panel B displays results for ARs and CARs, where the top and bottom 5\% are dropped. Panel C shows results for average scaled AR and CAR, i.e., AR and CAR divided by regression residual standard deviation of the estimation period. Here, standard errors in parenthesis are computed using the variance of scaled abnormal returns under the assumption of no-event induced variance, which is $(\mathrm{T}-\mathrm{p}-1) /(\mathrm{T}-\mathrm{p}-3)$, where $\mathrm{T}$ and $\mathrm{p}$ are the length of the estimation window and the number of explanatory variables in the market model. Standard errors in brackets are again calculated using the cross-section standard deviation of scaled ARs and scaled CARs to account for variance inflation at the announcement day. Panel D augments one factor market model by including Datastream industry index for the respective company in addition to market model (10 different industries based on ICB-classification). Panel E generates for each appointee-firm observation placebo announcements dates, which are 30, 50, 70, 90, 110, 130 and 150 days prior to the true announcement date. For these placebo events ARs and CARs are computed in the same way as before and reported in this panel. ***, **, * denote statistical significance at the $1 \%, 5 \%$ and $10 \%$ levels, respectively. 


\begin{tabular}{|c|c|c|c|}
\hline & $\begin{array}{l}\text { Number } \\
\text { of Obs. }\end{array}$ & $\begin{array}{c}\text { Abnormal Return } \\
(\%):[0]\end{array}$ & $\begin{array}{c}\text { Cumulative Abnormal Return } \\
(\%):[0,+1]\end{array}$ \\
\hline \multicolumn{4}{|l|}{ Panel A: Baseline } \\
\hline All appointees & 85 & $\begin{array}{c}0.79 \\
(0.40)^{*} \\
{[0.46]^{*}}\end{array}$ & $\begin{array}{l}1.05 \\
(0.57)^{*} \\
{[0.50]^{* *}}\end{array}$ \\
\hline \multicolumn{4}{|c|}{ Panel B: Subsamples - Firm position } \\
\hline Board member & 59 & $\begin{array}{c}0.96 \\
(0.52)^{*} \\
{[0.64]}\end{array}$ & $\begin{array}{c}1.29 \\
(0.74)^{*} \\
{[0.69]^{*}}\end{array}$ \\
\hline Non-board member & 26 & $\begin{array}{c}0.41 \\
(0.58) \\
{[0.34]}\end{array}$ & $\begin{array}{c}0.49 \\
(0.82) \\
{[0.39]}\end{array}$ \\
\hline
\end{tabular}

Panel C: Subsamples - Position at the defense department

\begin{tabular}{lccc}
\hline \multirow{3}{*}{ Top pay-grades } & \multirow{4}{*}{40} & 0.55 & 1.07 \\
& & $(0.58)$ & $(0.82)$ \\
& & {$[0.83]$} & {$[0.70]$} \\
Other high pay-grades & 45 & $(0.56)^{*}$ & 1.03 \\
& & {$[0.45]^{* *}$} & $(0.80)$ \\
\hline
\end{tabular}

Panel D: Subsamples - Party of nomination

\begin{tabular}{lccc}
\hline & & 1.24 & 1.71 \\
Democratic & 43 & $(0.71)^{*}$ & $(1.01)^{*}$ \\
& & {$[0.83]$} & {$[0.92]^{*}$} \\
Republican & 0.33 & 0.37 \\
& 42 & $(0.37)$ & $(0.52)$ \\
\hline \hline
\end{tabular}

Notes: The sample is based on appointments to the private sector of (former) political appointees to the U.S. Department of Defense in the years 1989 to 2011. Abnormal returns relate to the announcements of (former) political appointees who were working (at least some time) for the U.S. Department of Defense during the last two years before their move to the private sector (for further details see Table 6). Standard errors in parenthesis are calculated on the basis of the standard deviation of estimation-period residuals. Standard errors in brackets are computed using the cross-section standard deviation of ARs and CARs, respectively, and account for variance inflation at the announcement day. Panel A reproduces the baseline results ("ex post") from Table 5 for comparability and the remaining panels offer various sample splits. Panel B shows results for former political appointees being nominated as a board member or in another position. Panel C distinguishes between the top two pay-grades and the next two levels of pay-grades in federal government of former political appointees. Panel D offers insights into the nominating party of former political appointee. Note that virtually all private sector announcements are unanticipated. $* * *, * *, *$ denote statistical significance at the $1 \%, 5 \%$ and $10 \%$ levels, respectively. 


\section{Figure 1: Kernel Densities for Political Appointments and Placebo Appointments}

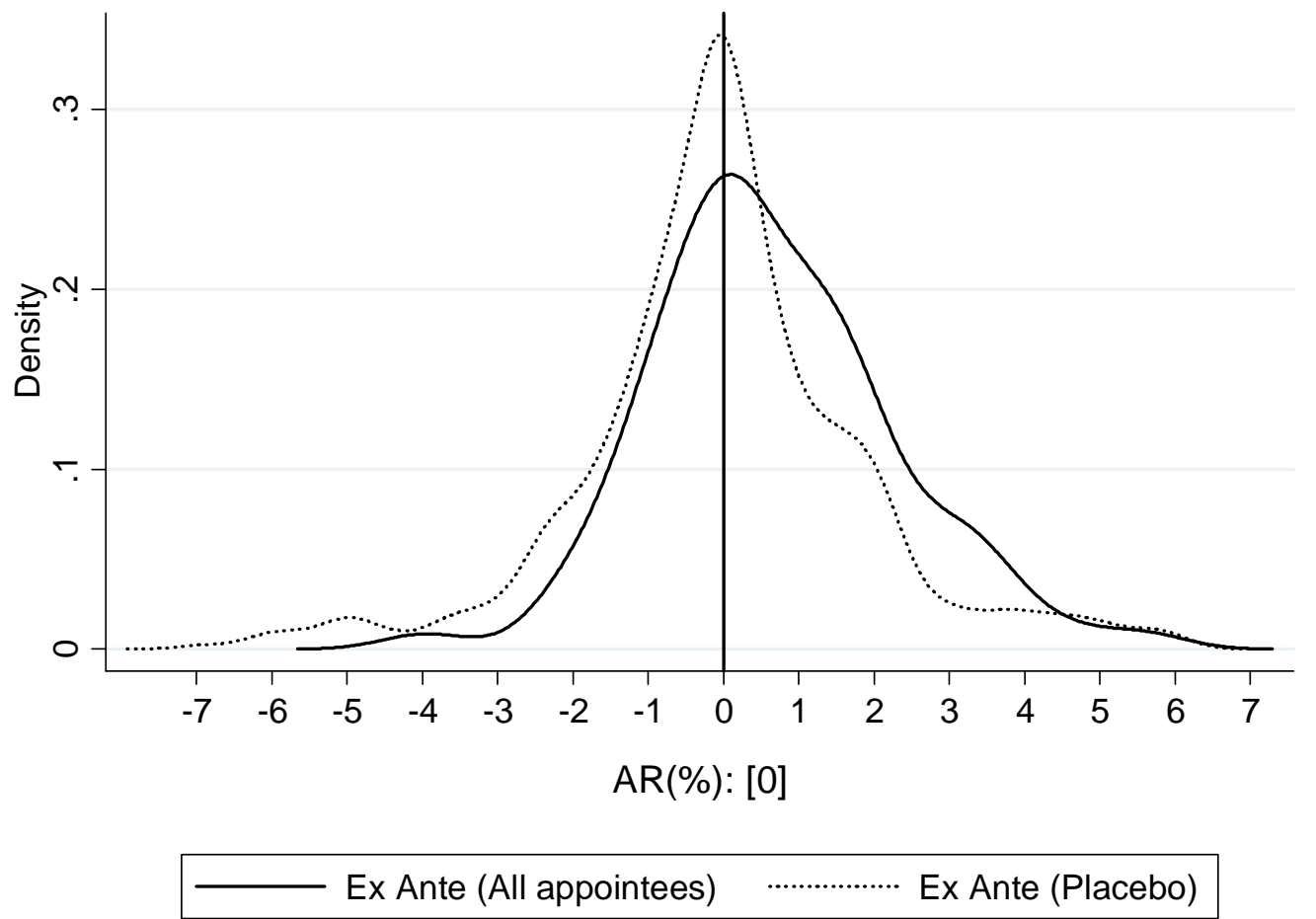

Notes: Figure 1 presents the cross-sectional distribution of abnormal returns for placebo appointments (dotted line) and for political appointments (straight line) at $\mathrm{t}=0$. The distributions are smoothed by a kernel density estimator. We generate the plot using a Gaussian kernel function. The optimal bandwidth is determined according to Silverman`s plug-in estimate (see Silverman, 1986, and Cameron and Trivedi, 2005). The Kolmogorov-Smirnov test for the equality of distributions is rejected at the 1 percent significance level. 


\section{Figure 2: Kernel Densities for Political Appointments and Placebo Appointments}

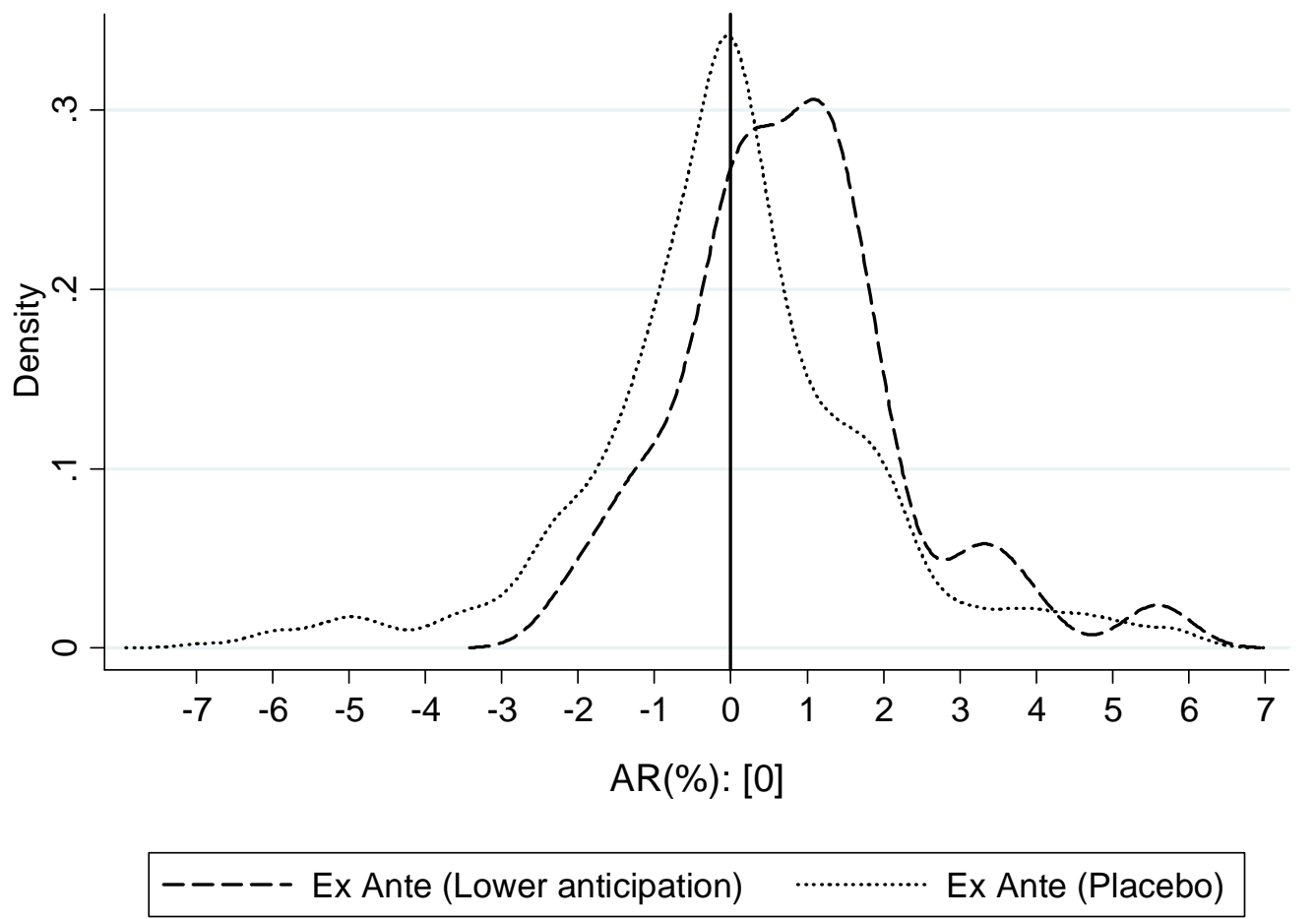

Notes: Figure 2 presents the cross-sectional distribution of abnormal returns for placebo appointments (dotted line) and for political appointments with lower anticipation (dashed line) at $\mathrm{t}=0$. The distributions are smoothed by a kernel density estimator. We generate the plot using a Gaussian kernel function. The optimal bandwidth is determined according to Silverman`s plug-in estimate (see Silverman, 1986, and Cameron and Trivedi, 2005). The Kolmogorov-Smirnov test for the equality of distributions is rejected at the 1 percent significance level. 


\section{Figure 3: Cumulative Abnormal Returns around Announcements of Political Appointments}

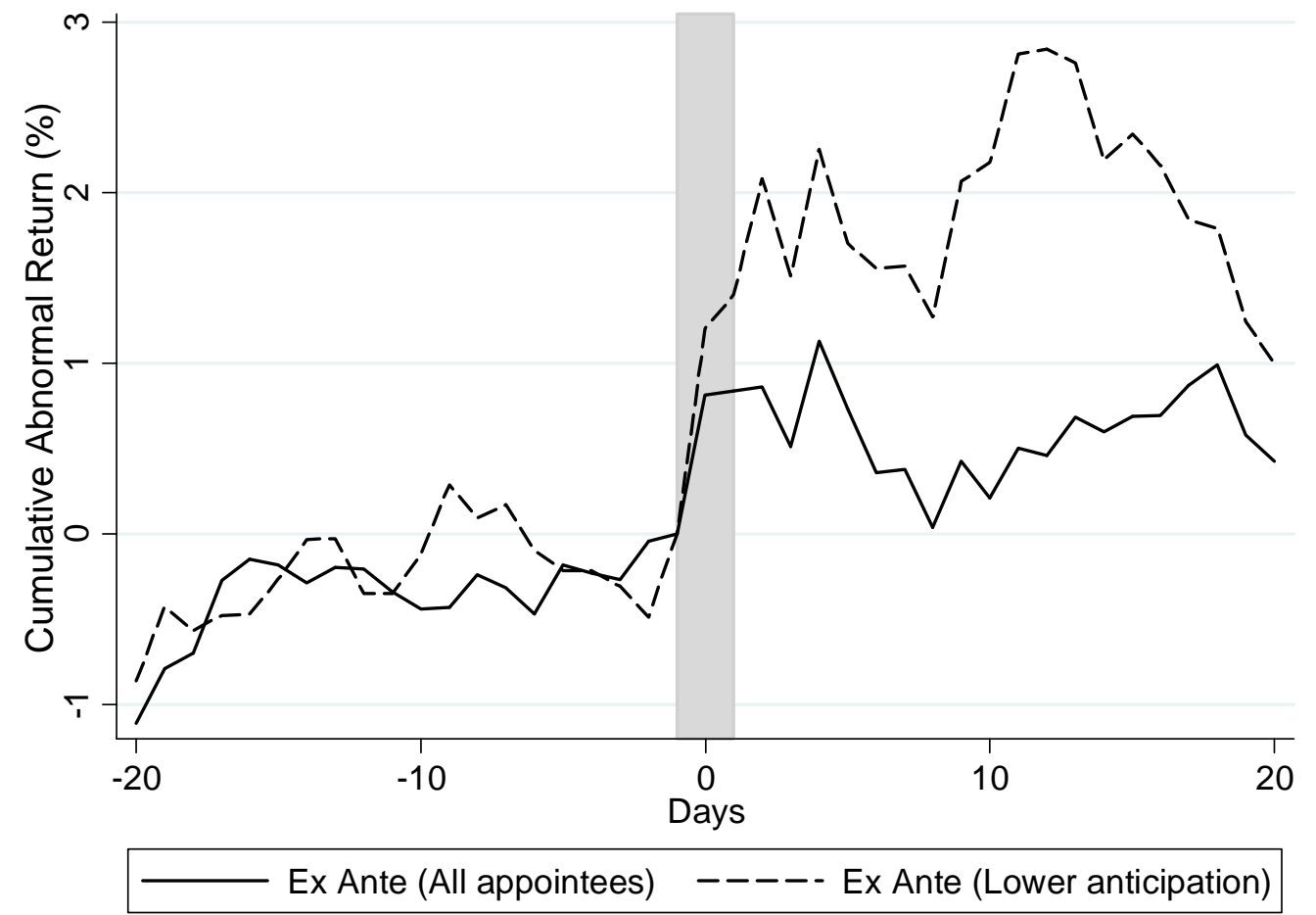

Notes: Figure 3 presents the average cumulative abnormal returns for day -20 up to the specified day for the 85 events in the baseline and the 39 less anticipated events. The shaded area represents the two-day event window. The average cumulative abnormal returns immediately preceding the event are set to zero. We deal with confounding factors as described in section 3 and in Table 2 . The vertical lines around the event date denote the time-period of the two-day cumulative abnormal returns reported in Tables 2 and 4. 


\section{Figure 4: Kernel Densities for Corporate Appointments and Placebo Appointments}

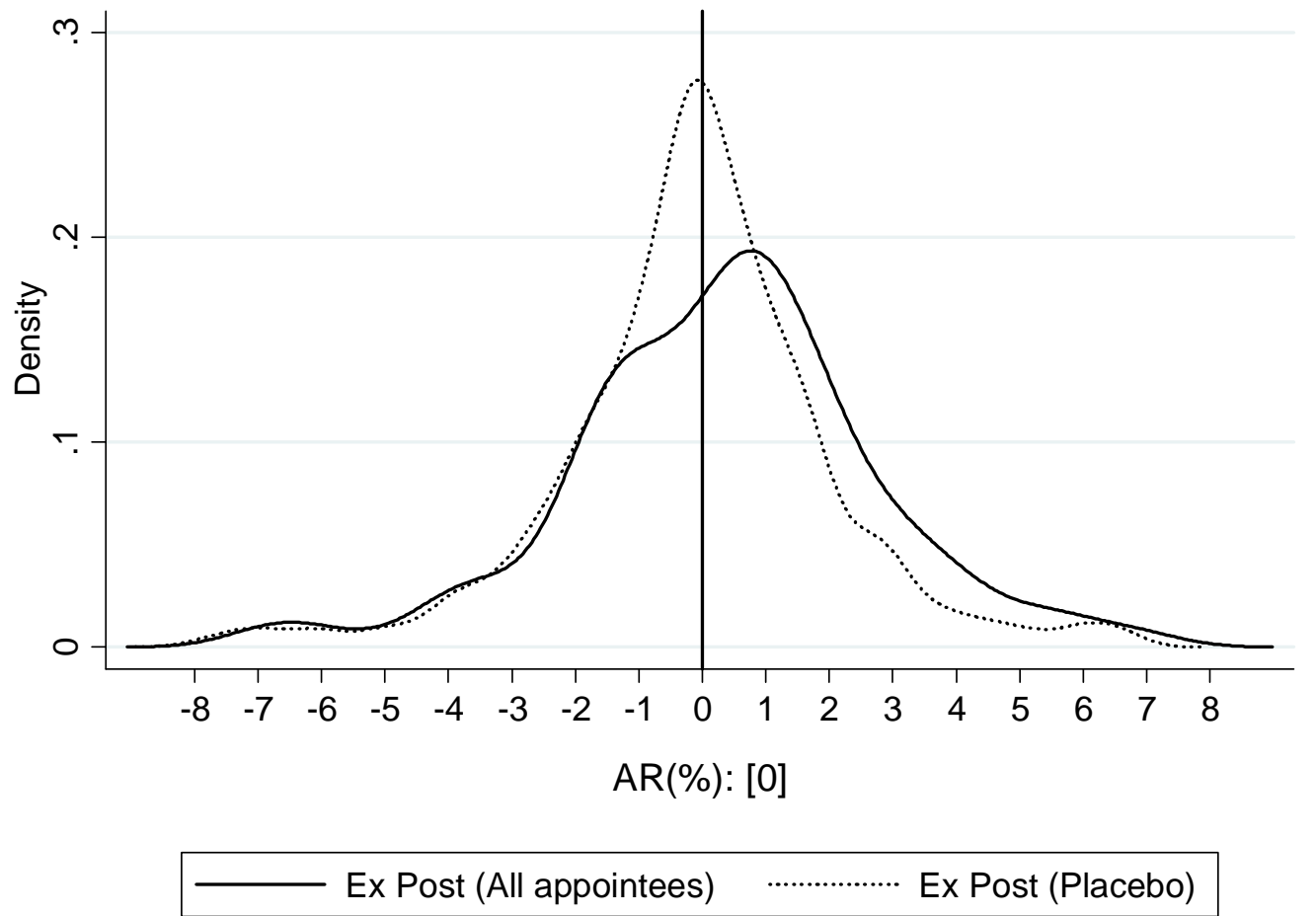

Notes: Figure 4 presents the cross-sectional distribution of abnormal returns for placebo appointments (dotted line) and for corporate appointments of (former) political appointees (solid line) at $\mathrm{t}=0$. The distributions are smoothed by a kernel density estimator. We generate the plot using a Gaussian kernel function. The optimal bandwidth is determined according to Silverman`s plug-in estimate (see Silverman, 1986, and Cameron and Trivedi, 2005). The Kolmogorov-Smirnov test for the equality of distributions is rejected at the 5 percent significance level. 


\section{Appendix Table A1. Sources used in full-text search (except SEC -filings)}

1. Newswires and press releases

The Associated Press

776

CQ Federal Department and Agency Documents, Congressional Press Releases,

Congressional Testimony, Congressional Testimony, Daily Monitor, Today, Weekly 337

PR Newswire

232

States News Service

228

United Press International (UPI) 190

$\begin{array}{ll}\text { U.S. Newswire } & 168\end{array}$

Federal News Service $\quad 159$

$\begin{array}{ll}\text { US Fed News } & 116\end{array}$

Business Wire $\quad 108$

White House Press Releases 103

Other $\quad 452$

2. Government publications and documents

Public Papers of the Presidents 340

Defense Department Documents and Publications $\quad 89$

White House Documents and Publications $\quad 73$

Congressional Documents and Publications, Hearing Transcripts, Schedules 52

US Department of Defense Information 29

$\begin{array}{ll}\text { Other } & 11\end{array}$

3. Newspapers
The Washington Post

The New York Times $\quad 318$

The Washington Times $\quad 294$

The Wall Street Journal $\quad 69$

Other 341

4. Magazines

The National Journal (including NJ's Congress Daily and NJ's Technology Daily) 241

Other $\quad 55$

5. Professional and trade journals (including newsletters)

Aerospace Daily $\quad 369$

Defense Daily $\quad 354$

Inside the Pentagon, the Army, the Navy, the Air Force, Missile Defense 296

Other $\quad 436$

6. Web based publications
Politico.com

Other 38

7. News transcripts
CNN

NPR $\quad 14$

\begin{tabular}{cr} 
Other & 43 \\
\hline Total & 7174 \\
\hline
\end{tabular} 